\title{
EDITORIAL: CURRENT RESEARCH AND PRACTICE IN TEACHING DISCIPLINARY LITERACIES
}

\section{Guest editors:}

\author{
Zuocheng Zhang, University of New England, Australia \\ Eveline Chan, University of New England, Australia
}

This Special Issue of ESP Today concerns the teaching of disciplinary literacies in tertiary ESP settings. ESP involves research and practice in the teaching and learning of English to prepare learners for competent performance in various workplace and academic settings (Dudley-Evans \& St John, 1998). What is required in target performance situations, an ontological and epistemological question, and how to deliver ready participants in such situations, a pedagogical question, have long been major concerns of ESP researchers and practitioners and have engendered a number of conceptual frameworks. For example, target competence has been conceptualised with reference to professional expertise (e.g. Bhatia, 2004), genre expertise and professional identity (e.g. Dressen-Hammouda, 2008; Tardy, 2009; Zhang, 2017), and academic literacy (e.g. Hyland, 2017). Given the recognition of specificity as a key feature in academic literacy practices across disciplines (e.g. Hyland, 2011; Shanahan, Shanahan, \& Misischia, 2011) and of diversity in tertiary students in the era of internationalisation of education, disciplinary literacies is arguably an important, if not essential, component of the target performance competence in tertiary ESP settings. Disciplinary literacies have been attributed increasing importance in recent publications concerned with discipline-specific writing, reading, speaking, listening, and viewing (e.g. Deane \& O’Neill, 2011; Derewianka \& Jones, 2016; Flowerdew \& Costley, 2016; Paltridge \& Starfield, 2013). Evolving in tandem with these changes in understanding disciplinary literacies are the innovations in teaching in English-medium Instruction (EMI) and Content and Language Integrated Learning (CLIL). All this has implications for ESP teacher development. 
The goal of this Special Issue is to engage in discussion and open up the dialogue between language specialists, that is, researchers and practitioners in ESP, EMI, CLIL, literacy education, and applied linguistics, and discipline specialists who participate in communities of practice characterised by highly specialised knowledge and discursive practices, to advance our understanding of disciplinary literacies and of the methodologies for teaching them. This introductory paper to the Special Issue begins by unpacking the concept of disciplinary literacies by gleaning its major dimensions, then briefly explores current practice in teaching disciplinary literacies from an ESP perspective. This is followed by a discussion of the role of ESP teachers and their professional development needs. The eight contributions to this Special Issue are then reviewed in light of this discussion. Finally, several pending issues are suggested for further exploration.

\section{WHAT ARE DISCIPLINARY LITERACIES?}

\subsection{Terms in the literature}

The terms, academic literacy, academic literacies, and disciplinary literacy, and the research and practices underlying them inform our understanding of disciplinary literacies as a representation of the target literate competence in academic disciplines. A literature search in the Scopus database using the key words of "academic literacy", "disciplinary literacy", "tertiary", and "English" yields interesting results regarding the use of these terms (see Table 1). It is clear from the table that there has been a substantial rise in the frequency of both terms, academic literacy and disciplinary literacy, in the literature over the last 15 years (from 1 to 93 and from 1 to 25 respectively). The term academic literacy has had a longer history (first appearing in 1991) and consequently, seems to be more widely used than disciplinary literacy (first appearing in 2000). It can also be seen from the table that the two terms increasingly co-occur in the same sources. A most recent example is the interconnected use of academic literacy and disciplinary literacy in the context of university academic literacy practices in Hyland (2017). This third result is supported by a search in the ProQuest database with the key words, "academic literacy" + "disciplinary literacy" + "tertiary" + "English" on the 19th September, 2017, which produced 1,304 results. Although it would be useful to sift through the literature to see how the terms academic literacy and disciplinary literacy are used, for example, their collocations in various contexts of use, it is evident that the two terms are closely connected in current research. 


\begin{tabular}{|l|c|c|}
\multicolumn{1}{|c|}{ SEARCH WORDS } & $\begin{array}{c}\text { FIRST APPEARANCE/NO. OF } \\
\text { APPEARANCES }\end{array}$ & NO. OF APPEARANCES IN 2016 \\
\hline $\begin{array}{l}\text { "academic literacy" + } \\
\text { "tertiary" + "English" }\end{array}$ & $1991 / 1$ & 93 \\
\hline $\begin{array}{l}\text { "disciplinary literacy" + } \\
\text { "tertiary" + "English" }\end{array}$ & $2000 / 1$ & 25 \\
\hline $\begin{array}{l}\text { "academic literacy" + } \\
\text { "disciplinary literacy" + } \\
\text { "tertiary" + "English" }\end{array}$ & $2005 / 1$ & 7 \\
\hline
\end{tabular}

Table 1. Terms related to literacy in the Scopus database

\subsection{Dimensions of disciplinary literacies}

\subsubsection{Specificity in disciplinary literacies}

The growing body of research on the distinctive knowledge structures, representational modes, language and discursive practices of different disciplines foregrounds the need for specificity in order to teach disciplinary literacies effectively (Hyland, 2017). From early linguistic studies on discipline-specific texts (e.g. Bazerman, 1988; Halliday, 1998; Martin, 1997), to sociological perspectives on disciplinarity (e.g. Christie \& Maton, 2011), and multimodal analyses of disciplinary discourses (e.g. Allori, Bateman, \& Bhatia, 2014; Camiciottoli \& Fortanet-Gómez, 2015; Lemke, 2002; O’Halloran, 2007), the literature sheds light on several major dimensions of disciplinary literacies as distinctive practices in specialised fields of knowledge. First of all, disciplinary literacies have their ontological basis, derived from the disciplinary content, skills, dispositions, and practices that characterise the target disciplines. They resemble the professional expertise that is theorised to represent target professional performance (Bhatia, 2004).

There is substantial empirical evidence for specificity in disciplinary literacy practices. This includes features of literacy artefacts like written texts, and also the literacy processes that discipline experts engage in. Much of this evidence has been in the form of detailed linguistic descriptions, particularly around genre and its various conceptualisations. Systemic functional linguistic (SFL) studies have contributed a wealth of research identifying the specific language features of specialised discourses, including field-related and technical vocabulary as well as the distinctive grammatical and textual patterns characterising genres in different disciplines such as in physics and the life sciences (e.g. Dreyfus, Humphrey, Mahboob, \& Martin, 2016; Halliday \& Martin, 1993), and the social sciences and humanities (e.g. Wignell, 2007). ESP approaches to genre have also yielded detailed descriptions of distinct structural sequences and linguistic features in 
academic research genres, for example, the Creating A Research Space (CARS) model for journal article introductions (Swales, 1990) is well known. Building on this early work, variation in the use of the CARS moves and steps has been identified across disciplines and cultures (e.g. Loi, 2010; Sanraj, 2002). Another example is the Issue, Rule, Application, and Conclusion (IRAC) sequence, which is vital in writing legal analyses in common law legal education (Jensen, 2002).

In more recent times, descriptions of discipline-specific texts and processes have also included an analysis of their multimodal features. Multimodal research has drawn attention to ways in which multiple semiotic resources interact with the language in constructing disciplinary knowledge, with a particular emphasis on visual representations and their specialised functions in different disciplines, for example, in physics (Doran, in press), mathematics (O'Halloran, 2008), and botany (McCarty \& Swales, 2017). A multiliteracies approach to disciplinary communication recognises the multiple sensory means through which humans are acculturated to engage with the environment, as well as the diversity of social contexts that these disciplinary communications traverse (Kalantzis, Cope, Chan, \& Dalley-Trim, 2016). For example, the co-occurrence of multiple communicative modes such as verbal language, facial expression, and gesture contributes to mitigating face-threatening communicative acts in academic presentations (Zhang, 2015). Similarly, research on literacy practices in tertiary settings has expanded its focus on reading and writing to include viewing and other processes, such as presentations of various kinds in academic settings (e.g. Camiciottoli \& Fortanet-Gómez, 2015).

In studies of literacy processes from a cognitive perspective, qualitative differences are also found across disciplines. Drawing on think-aloud protocols and interviews with discipline experts, researchers are able to uncover these experts' processes for reading, writing, thinking, and their rationalisation for these practices (Fang \& Schleppegrell, 2010; Shanahan et al., 2011). For example, Shanahan and colleagues (2011) found that historians evaluate authors of the sources they read to detect possible biases in historical interpretation while chemistry experts do not do this when they are in the process of reading their selected sources. Bazerman's (1985) research on physicists' reading in their field shows reading as an integral part of the dynamic research process. Such disciplinespecific practices around the processes and products of literacy give each disciplinary area a distinct feel and reflect the specific nature of disciplinary knowledge production, consumption, communication, and evaluation.

\subsubsection{Disciplinary literacies as ongoing and developmental}

Discipline literacies are developmental and are acquired over time. In a longitudinal study of writing across the school years, Christie and Derewianka (2008) charted the intertwining of subject matter, language and literacy development from early childhood to late adolescence in Australia. They found 
that over the course of schooling, students not only face increasing technicality in subject content, they also encounter further specialisation of textual and grammatical patterns in different subject areas, particularly with the resources of technicality, grammatical metaphor, abstraction and appraisal (Christie, 2013). The specialised meaning-making resources used to represent curriculum knowledge begin to approximate the disciplinary literate practices, and this is increasingly evident from the start of secondary schooling (Fang, 2012; Freebody, Chan, \& Barton, 2013).

This developmental trajectory is also evidenced in longitudinal studies of disciplinary literacy development in tertiary settings. For example, DressenHammouda (2008) tracked literacy practices in field geology acquired by a student going through undergraduate, postgraduate, and $\mathrm{PhD}$ stages of learning. As the student advanced through the stages of learning, he acquired more nuanced features of the writing in his field. Through these learning processes, his disciplinary literacy and his professional identity were in a mutually enhancing relationship. This finding resonates with Artemeva's (2009) research into engineering students' learning paths. As these engineers-in-the-making progressed in their learning journey, they grew in awareness and mastery of the literacy practices that characterised professional discursive practices in engineering. In terms of the theory of indexicality (Bucholtz \& Hall, 2005), learning to write in the disciplines of geology and engineering is an ongoing process of learning to index, that is, to relate textual features, both linguistic and multimodal, to a professional identity.

\subsubsection{Disciplinary literacies and diversity}

In addition to specificity in disciplinary communications, there is diversity in both the student population and the literacy practices they bring to the university. The idea of academic literacies emerged in the context of the New Literacy Studies championed by Street and associates (Street, 2003) to highlight the diversity among both academic participants and disciplines, and to advocate academic literacies as an epistemological approach to viewing and teaching literacy practices. This orientation towards diversity subsumes the understandings of academic literacy as generic skills that are transferrable across disciplines, and academic literacy as academic socialisation (Lea \& Street, 1998; Lillis \& Scott, 2007). Building on this conception, the term disciplinary literacies, rather than disciplinary literacy, has been adopted in response to the plurality of literacy practices present in the classroom and in disciplinary communities of practice. 


\subsection{Working definition of disciplinary literacies}

On the basis of the above discussion, disciplinary literacies may be defined, for exploratory purposes, as discipline-specific speaking, listening, reading and viewing, writing and creating of verbal and multimodal texts as integral to disciplinary activities, and as a way of empowering newcomers to a discipline with the tools for both functioning in the discipline and negotiating their place in it.

\section{TEACHING DISCIPLINARY LITERACIES FROM AN ESP PERSPECTIVE}

Disciplinary literacies, as outlined in the last section, involves both linguistic processes and disciplinary habits of mind (see Moje, 2007 for a comprehensive discussion). As ESP has traditionally focused on the "language (grammar, lexis, register), skills, discourse and genres" (Dudley-Evans \& St John, 1998: 5) in the activities of the disciplines it serves, it is faced with a challenge to adapt to the requirements of teaching disciplinary literacies in a way that approximates the discipline-specific nature of knowledge production, communication, and evaluation. Although ESP typically draws on the "underlying methodology and activities of the disciplines it serves" (Dudley-Evans \& St John, 1998: 4), these methodologies and activities are in urgent need of clarification so they can be made explicit in the teaching of disciplinary literacies.

ESP is also facing challenges from EMI and CLIL. EMI and CLIL have emerged in response to the spread of English as an international language and the internationalisation of education. EMI serves to accommodate the internationalisation of education where universities are running academic programmes in which subject specialists need to deliver their specialised content in English (e.g. Airey, 2016). CLIL is a response to the European vision to learn a foreign language apart from one's native language against the backdrop of a crowded curriculum in the hope that the subject matter and the language specific to the subject matter are both given due attention (Coyle, Hood, \& Marsh, 2010). (For a recent discussion of EMI and CLIL in a unified framework of content-based instruction [CBI], see Snow \& Brinton, 2017). While the rise of EMI and CLIL may be seen as a potential threat or challenge to ESP, these three approaches are actually in a complementary rather than mutually exclusive relationship. They each serve different needs in different contexts; for example, there is the suggestion that ESP and CLIL serve low-proficiency students and EMI is for high proficiency/advanced students (e.g. Aguilar, 2017), and may enrich each other by learning from one another's underpinning thinking, methods, and techniques. After all, ESP professionals have played a vital role in both EMI and CLIL. For example, they assist discipline specialists in identifying and addressing the literacy demands specific to various subject disciplines (Arnó-Macià \& Mancho-Barés, 2015). 


\section{ESP TEACHER DEVELOPMENT}

As CLIL and EMI are gaining ground, there have been concerns about the future of ESP practitioners' professional identities and careers - will they be displaced or phased out? There are certainly challenges for ESP teachers from EMI and CLIL practitioners. However, ESP specialists have a strong case for a legitimate role in teaching disciplinary literacies. ESP is an interdisciplinary endeavour (DudleyEvans \& St John, 1998) and the narrow-angled approach to course design has much to offer for handling discipline-specific literacy practices. The viability of ESP professionals also depends on their unique contribution to disciplinary literacies teaching. The knowledge base of ESP practitioners is typically in applied linguistics and language education. They are among the consumers and producers of the metalanguage for literacy demands. This dual role is expected to continue. While discipline experts are becoming more aware of the specific literacy practices of their disciplines, they are unlikely to displace language experts like ESP professionals who are especially trained to identify and evaluate the linguistic demands of disciplinary learning and design the kinds of pedagogy to support and evaluate students in meeting these demands. As exemplified in Zhang (2016), the subject specialist Leo was unable to scope the literacy demands of his students and recognised the need to seek an optimal balance between the gravitation towards the subject matter and the teaching of business discourse. ESP specialists nowadays are a diverse cohort. There are language and literature-background ESP specialists (e.g. Zhang, 2016), and also academic and science or engineeringbackground ESP practitioners (e.g. Airey, 2016; Artemeva, 2009). These different members of the ESP community of practice bring with them different areas of expertise and should be treated differently in discussions of the viability of ESP.

Finally, ESP specialists have a role to play in coaching EMI/CLIL specialists in identifying the features of disciplinary literacies and the appropriate pedagogies for delivering them (Aguilar, 2017; Arnó-Macià \& Mancho-Barés, 2015). Despite the potential challenge for ESP from the emergence of EMI and CLIL in tertiary education, EMI and CLIL may actually contribute to delineating ESP and its research and practice and provide a space for ESP to expand into.

Professional development for ESP teachers, however, needs to consider several key issues. In order to contribute substantively to the teaching of disciplinary literacies, their specialised knowledge of linguistics and language pedagogy needs to be linked to an understanding of how disciplinary meaningmaking works. That is, teachers need be able to translate the general principles and theories of language and literacy learning to the teaching of specialised literacy practices in specific disciplines. This requires an understanding of disciplinary ways of producing, consuming, communicating, and evaluating knowledge, and apprenticing novices into the disciplines. Such understandings may be cultivated in ESP teacher education programmes where language analysis and pedagogies are contextualised in relation to disciplinary literacy practices. ESP 
specialists may enhance these understandings by collaborating with discipline experts through team-teaching, or at least use discipline lecturers as informants if it is infeasible for them to be close partners in teaching disciplinary literacies (Hyland, 2017).

\section{THIS SPECIAL ISSUE}

The purpose of this Special Issue of ESP Today is to stimulate dialogue between discipline experts, ESP practitioners, and literacy educators by highlighting the complementary roles they play in teaching the literacies of academic disciplines in tertiary education settings. The six articles and two review papers in this Issue each bring a different perspective to the themes outlined above; they exemplify a range of work being done at the intersection of various ESP, EMI, and CLIL approaches to teaching disciplinary literacies. A common thread throughout the papers is the need for close collaboration between the EFL/EAP/ESP English language specialists and the discipline experts they complement in supporting students' apprenticeship into specialised communities of practice (Wegner, 1998) in the various disciplines and their constantly evolving sub-disciplines.

In the first paper in this Special Issue, Janna Fox and Natasha Artemeva draw attention to a pressing problem faced by institutions across the university sector: the gap between general English proficiency requirements on entry to EMI degree programmes and the specific disciplinary literacy demands of tertiary study in highly specialised fields. A global trend in response to this situation has been post-entry language assessment. The authors present a strong case for collaboration between ESP experts and engineering stakeholders to develop discipline-based criteria for such diagnostic assessments, with the purpose of identifying first-year engineering students in need of academic support. The first phase of their longitudinal, mixed-methods study compared how language experts and engineering experts at a Canadian university rated a generic writing task. They found that the English language experts and the engineering experts differed markedly in "their interpretations of how writing is structured or shaped in response to an engineering context of use" (p. 158). In response to this finding, an engineering writing task was designed with input from engineers for the second phase of the study. Student performance on the generic writing task and the domain-specific engineering task were compared but it was found that neither of the tasks were well-suited for the purposes of diagnostic assessment. In phase three of the study, ESP experts and engineering experts jointly developed an engineering-specific, ESP-based diagnostic task and rubric which was delivered in the context of disciplinary learning. This domain-specific task proved to be efficacious in identifying dimensions of risk and developing individual learning profiles for students requiring academic support. This carefully executed study, while focused on engineering communities of practice, has clear implications for 
other fields for engaging the expertise of both discipline and ESP specialists in designing domain-specific writing tasks and disciplinary assessment criteria. This study also demonstrates the resilience of ESP specialists in thinking beyond the comfort zone of their own language expertise by taking the initiative in collaborating with discipline specialists and incorporating their perspectives of disciplinary literacy practices.

In a similar vein, Birna Arnbjörnsdóttir and Patricia Prinz highlight the need for discipline specificity when preparing students for academic writing in EMI programmes. They report on their study of an English for Specific Academic Purposes (ESAP) programme at an Icelandic university, designed to address students' lack of discipline-specific writing competencies for tertiary study despite being admitted to EMI programmes which presume a high level of English language proficiency. The programme, which focuses on 'humanities-based, thesisdriven writing', commendably takes into consideration both psychological and sociocultural dimensions in developing learner autonomy and self-efficacy through strategies for managing cognitive load and mediating learning through a cognitive apprenticeship model. While the data are limited to a cohort of linguistics and literature majors, the findings regarding the efficacy of the pedagogical principles applied are promising and demonstrate potential for adaptation in disciplines beyond the humanities.

The growing challenges for EMI are also taken up by Ruth Breeze and Carmen Sancho Guinda in their study of collaborative practice at two Spanish universities. They adopt genre as "a fertile site of intersection between content and form, disciplinary and transversal lifelong skills, and different areas of expertise" (p. 197) and propose an innovative approach to teaching genre in the disciplines of Engineering and Journalism, taking two key competencies, critical and creative thinking, as the basis of an integrative pedagogy. Beginning with a needs analysis, the authors reveal how very different the communicative challenges can be for students in the two disciplines. They argue that critical and creative thinking provide indispensable tools for learning about cross-disciplinary genres as well as discipline-specific genres through a multi-perspective model of professional discourse. Their argument is a compelling one, supported by illustrative examples of genre-based strategies which open up new "communicative spaces" (p. 199) not only for team-teaching and professional development involving exchanges of expertise between content teachers and applied linguists, but also for students to become critical and creative transformers of knowledge as they traverse the ground between higher education and professional practice. Their study also demonstrates how established concepts such as genre may be redeployed and framed to incorporate discipline-relevant competencies such as creative thinking and creativity.

Turning our attention to reading practices in bioengineering, Milevica Bojović explores the research space between content-area reading and disciplinary literacies, adapting existing validated measures of EFL reading strategies to study 
how experts and novices approach reading in EFL biotechnology engineering contexts. Her substantial study of 94 undergraduate biotechnical science students and 46 biotechnology engineering experts at a university in Serbia shows the increasing pressure on EFL teachers to go beyond teaching content-area literacy strategies to engaging their students more fully in reading discipline-based texts. This preliminary foray into examining reading practices in a biotechnology disciplinary setting highlights the current paucity of research which provides rich description of the distinctive features of discipline-specific cognitive literacy processes that can readily inform the teaching of specialised reading practices in FL disciplinary teaching contexts.

The last two articles in the Special Issue explore the contributions of ESP practitioners and content lecturers to teaching disciplinary literacies through their own eyes. In a case study of ESP lecturers at a private Spanish university, Monika Woźniak considers the changing, multiple roles of ESP specialists and the crucial role they play in mediating between the disciplines and participating in students' academic and disciplinary development. She challenges traditional disciplinary divisions and argues for a more integrated approach to content and language teaching in ESP programmes. Despite being limited to one institutional site, the study provides rich insights into the experiences of the ESP lecturers and how they perceive their shifting roles and the challenges of their profession. As ESP teachers, they provide language support for students; as CLIL tutors for faculty staff they provide linguistic and pedagogical expertise for integrating the teaching of English into content areas in consultation with subject specialists; as language experts, they mediate the disciplinary communication within subjects; however, it was perceived that their role was undervalued compared to that of content lecturers. Far from the scenario of ESP teachers becoming redundant in the push for internationalisation of higher education through EMI and CLIL, this study affirms the important, albeit changing role of ESP professionals in the joint venture of disciplinary literacies teaching.

Complementing Woźniak's study of ESP lecturers, Guzman Mancho-Barés and Elisabet Arnó-Macià provide critical insights into the practices and expectations related to discipline-specific genre pedagogy, this time from the point of view of EMI lecturers. In a study of EMI implementation across seven Catalan universities, the authors take a "behind-the-scenes" approach by examining policy documents, and interviewing EMI lecturers about their teaching practices in STEM (Science, Technology, Engineering and Mathematics) degree programs. The study revealed that despite institutional support for EMI lecturers at policy level, EMI training offered to lecturers at the implementation level was largely inadequate, with no explicit focus on the genres and texts considered to be an integral part of disciplinary learning. Teachers reported a reluctance to address the linguistic and/or communication issues in their classes as this was perceived to be the role of language specialists. Like Breeze and Sancho Guinda, the authors make a strong case for the centrality of genre in disciplinary learning and advocate for 
collaboration between ESP instructors and EMI lecturers to design genre-based EMI courses to make disciplinary literacies visible. Again, this paper brings to the fore the need for knowledge and expertise in teaching explicitly about disciplinespecific text features and practices to complement the teaching of disciplinespecific subject matter.

The Special Issue closes with reviews of two recent publications pertinent to the issues raised in the articles. Margaret Cargill, in her review of the book Discipline-specific writing: Theory into practice edited by John Flowerdew and Tracey Costley, highlights the "pedagogical practices and possibilities" (p. 291) in each contribution to the volume. She provides a helpful synopsis of each chapter which recognises the complexity of tasks and roles that teachers engage in to assist their students in meeting the demands of writing in different disciplines. In the second review, John Airey provides a brief historical sketch of CLIL, and draws attention to the distinction between CLIL and EMI in tertiary settings. This sets the context for his critical review of the chapters in the volume, Conceptualising integration in CLIL and multilingual education edited by Tarja Nikula, Emma Dafouz, Pat Moore, and Ute Smit. Airey identifies the key features of each chapter and highlights the diversity and strength of the theoretical and methodological lenses in the work as a whole. He also expresses a concern about the book that perhaps reflects the reality of implementing CLIL, and indeed the whole endeavour around teaching disciplinary literacies, that is, the hope of more input from mainstream content specialists.

\section{PENDING ISSUES}

In this Special Issue, a conversation is unfolding between researchers and practitioners across Europe and North America about the need for disciplinespecific teaching and assessment in ESP with a common purpose of apprenticing students into professional roles in the communities of practice of specialised disciplines. Considered together, the studies of practice reported in these six articles articulate in rich detail the situated practices and challenges of teaching disciplinary literacies in a small number of institutions. While providing a predominantly European perspective on the role of ESP in the disciplinary teaching at a time when EMI and CLIL are gaining momentum, the papers in this Special Issue echo the convergence of findings from international research in applied linguistics, EMI, CLIL, ESP, literacy education, and disciplinary literacies in school and tertiary settings that closer collaboration between language (and literacy) specialists and discipline experts is critical in the effective induction of students into the practices and discourses of the disciplines.

The papers here highlight the expanding role for ESP practitioners in teaching disciplinary literacies in a number of areas, for example, in tertiary settings where there is a trend towards embedding academic literacies support 
within disciplinary teaching contexts; or where new collaborations in teaching and professional development are forged which recognise and value the combined expertise of specialist linguistic knowledge and discipline knowledge in the teaching of disciplinary literacies; and in the collaborative practice in designing teaching, learning, and assessment for diagnosis of risk as well as mastery of disciplinary content.

A recognition that different disciplines engage different methodologies to investigate and build disciplinary knowledge necessitates more specialised teaching to complement general approaches to academic literacies. In order for research-informed teaching to take place, linguistic accounts of disciplinarity need to be made accessible to practitioners in the field. There is still much work to be done in 'translating' or recontextualising this knowledge for pedagogical purposes, tailored to meet student needs in a diverse range of institutional and educational settings, addressing not only the linguistic but also the multimodal aspects of meaning-making in the disciplines. Continued longitudinal research is also needed into developing professional identities, particularly around the induction of novices into professional discourse communities.

While the call for papers for this Special Issue was worldwide and open to discipline experts as well as ESP practitioners, the majority of the papers accepted for inclusion in this Issue were authored by researchers from Europe, reflecting to an extent the momentum in disciplinary literacies teaching in the region. Similarly, both discipline experts and linguistics experts were approached to act as reviewers for the Issue. While the reviewers represent a much broader reach of international experts, there was limited participation by discipline experts. Such a concentration of ESP and applied linguistics specialists as both contributors and expert reviewers is indicative of the disparity between expert groups in engaging with the agenda of teaching disciplinary literacies in tertiary settings on a global scale.

One imminent issue that stands out for research attention is the theorisation of disciplinary literacies teaching. As an interdisciplinary endeavour, teaching disciplinary literacies requires concerted efforts on the part of ESP specialists and discipline experts, both to deliver quality teaching and to generate insights into the ontological, epistemological, and pedagogical dimensions of disciplinary literacies to develop a coherent framework for teaching the highly specialised literacies of the disciplines. These understandings will positively feedback into ESP, EMI, and CLIL course development and policy making for research funding and teacher development support. It is also worth exploring the implications for disciplinary literacies teaching of theme-based academic undertakings in the $21^{\text {st }}$ century in contrast with the discipline-based academic practices we have inherited from the $20^{\text {th }}$ century. 


\title{
6. ACKNOWLEDGEMENTS
}

We thank the authors of the articles and book reviews in this Special Issue for disseminating their work and sharing their insights and expertise in this forum: the practices detailed in the studies reported as well as the questions raised that are yet to be answered have created fertile ground for further research and discussion.

We also acknowledge the substantial contribution of the expert reviewers for this Special Issue and thank them for their generous feedback and timely reviews of the articles. They are listed in alphabetical order:

\author{
Patrizia Anesa, University of Bergamo (Italy) \\ Elisabet Arnó-Macià, Polytechnic University of Catalonia (Barcelona, Spain) \\ Natasha Artemeva, Carleton University (Ottawa, Canada) \\ Ruth Breeze, Universidad de Navarra (Spain) \\ Tracey Costley, University of Essex (Colchester, UK) \\ Devo Devrim, University of New England (Armidale, Australia) \\ Ruth Fielding, University of Canberra (Australia) \\ Evan Frendo (Berlin, Germany) \\ Miguel Garcia-Yeste, University of Gothenburg (Sweden) \\ Julio Gimenez, University of Westminster (London, UK) \\ Feng Haiying, University of International Business and Economics (Beijing, \\ China) \\ Jing Hao, The Hong Kong Polytechnic University (China) \\ Jane Lung, Macao Polytechnic Institute (China) \\ María José Luzón, Universidad de Zaragoza (Spain) \\ Guzman Mancho-Barés, University of Lleida (Spain) \\ Davide Mazzi, University of Modena and Reggio Emilia (Italy) \\ Špela Mežek, Linnaeus University (Växjö, Sweden) \\ Catherine Nickerson, Zayed University (Dubai, UAE) \\ Carmen Sancho Guinda, Universidad Politécnica De Madrid (Spain) \\ Hairong Shang-Butler, University of Rochester (USA) \\ Miloš Tasić, University of Niš (Serbia) \\ Lindy Woodrow, The University of Sydney (Australia).
}

Finally, we would like to express our sincere thanks to the Editorial team of ESP Today for the opportunity to guest-edit this Special Issue, and for their generous support in the timely publication of this Issue: Nadežda Silaški, University of Belgrade (Serbia), Editor-in-Chief; Tatjana Đurović, University of Belgrade (Serbia), Associate Editor; and Ana Bocanegra-Valle, University of Cadiz (Spain), Book Review Editor. 


\section{References}

Aguilar, M. (2017). Engineering lecturers' views on CLIL and EMI. International Journal of Bilingual Education and Bilingualism, 20, 722-735.

Airey, J. (2016). EAP, EMI or CLIL? In K. Hyland, \& P. Shaw (Eds.), The Routledge handbook of English for specific purposes (pp. 71-83). New York: Routledge.

Allori, P. E., Bateman, J. A., \& Bhatia, V. K. (2014). Evolution in genre: Emergence, variation and multimodality. Bern/Berlin/Bruxelles: Peter Lang.

Arnó-Macià, E., \& Mancho-Barés, G. (2015). The role of content and language in content and language integrated learning (CLIL) at university: Challenges and implications for ESP. English for Specific Purposes, 37, 63-73.

Artemeva, N. (2009). Stories of becoming: A study of novice engineers learning genres of their profession. In C. Bazerman, A. Bonini, \& D. Figueiredo (Eds.), Genre in a changing world (pp. 158-178). Fort Collins, Colorado: The WAC Clearinghouse/West Lafayette, Indiana: Parlor Press. Retrieved from http://wac.colostate.edu/books/genre/

Bazerman, C. (1985). Physicists reading physics: Schema-laden purposes and purposedriven schema. Written Communication, 2, 3-23.

Bazerman, C. (1988). Shaping written knowledge: The genre and activity of the experimental article in science. Madison: University of Wisconsin Press.

Bhatia, V. K. (2004). Worlds of written discourse: A genre-based view. London: Continuum.

Bucholtz, M., \& Hall, K. (2005). Identity and interaction: A sociocultural linguistic approach. Discourse Studies, 7, 585-614.

Camiciottoli, B. C., \& Fortanet-Gómez, I. (Eds.) (2015). Multimodal analysis in academic settings: From research to teaching. London: Routledge.

Christie, F. (2013). Language education throughout the school years: A functional perspective. New York: John Wiley \& Sons Inc.

Christie, F., \& Derewianka, B. (2008). School discourse: Learning to write across the years of schooling. London/New York: Continuum.

Christie, F., \& Maton, K. (Eds.) (2011). Disciplinarity: Functional linguistics and sociological perspectives. London/New York: Continuum.

Coyle, D., Hood, P., \& Marsh, D. (2010). Content and language integrated learning. Cambridge: Cambridge University Press.

Deane, M., \& O’Neill, P. (Eds.) (2011). Writing in the disciplines. Basingstoke, UK: Palgrave Macmillan.

Derewianka, B., \& Jones, P. (2016). Teaching language in context (2nd ed.). Oxford: Oxford University Press.

Doran, Y. J. (in press). The discourse of physics: Building knowledge through language, mathematics and image. London: Routledge.

Dressen-Hammouda, D. (2008). From novice to disciplinary expert: Disciplinary identity and genre mastery. English for Specific Purposes, 27, 233-252.

Dreyfus, S. J., Humphrey, S., Mahboob, A., \& Martin, J. R. (2016). Genre pedagogy in higher education: The SLATE Project. London: Palgrave Macmillan.

Dudley-Evans, T., \& St John, M. J. (1998). Developments in English for specific purposes: A multidisciplinary approach. Cambridge: Cambridge University Press.

Fang, Z. (2012). Language correlates of disciplinary literacy. Topics in Language Disorders, $32(1), 19-34$. 
Fang, Z., \& Schleppegrell, M. J. (2010). Disciplinary literacies across content areas: Supporting secondary reading through functional language analysis. Journal of Adolescent \& Adult Literacy, 53, 587-597.

Flowerdew, J., \& Costley, T. (Eds.) (2016). Discipline-specific writing: Theory into practice. London: Routledge.

Freebody, P., Chan, E., \& Barton, G. (2013). Literacy and curriculum: Language and knowledge in the classroom. In K. Hall, T. Cremin, B. Comber, \& L. Moll (Eds.), International handbook of research in children's literacy, learning and culture (pp. 304-318). Maiden, Mass.: Wiley-Blackwell.

Halliday, M. A. K. (1998). Things and relations: Regrammaticalising experience as technical knowledge. In J. R. Martin, \& R. Veel (Eds.), Reading science: Critical and functional perspectives on discourses of science (pp. 185-235). London/New York: Routledge.

Halliday, M. A. K., \& Martin, J. R. (1993). Writing science: Literacy and discursive power. London/Washington, DC: The Falmer Press.

Hyland, K. (2011). Disciplinary specificity: Discourse, context, and ESP. In D. Belcher, A. M. Johns, \& B. Paltridge (Eds.), New directions in English for specific purposes research (pp. 6-24). Ann Arbor, MI: University of Michigan Press.

Hyland, K. (2017). English in the disciplines: Arguments for specificity. ESP Today, 5(1), 523. https://doi.org/10.18485/esptoday.2017.5.1.1

Jensen, C. (2002). Legal problem questions: Analyzing rhetorical strategies using "IRAC". In C. Candlin (Ed.), Research and practice in professional discourse (pp. 463-498). Hong Kong: City University of Hong Kong Press.

Kalantzis, M., Cope, W., Chan, E., \& Dalley-Trim, L. (2016). Literacies (2nd ed.). Port Melbourne, Vic: Cambridge University Press.

Lea, M. R., \& Street, B. V. (1998). Student writing in higher education: An academic literacies approach. Studies in Higher Education, 23, 157-172.

Lemke, J. (2002). Multimedia semiotics: Genres for science education and scientific literacy. In M. Schleppegrell, \& M. C. Colombi (Eds.), Developing advanced literacy in first and second languages (pp. 21-44). Mahwah, NJ: Erlbaum.

Lillis, T., \& Scott, M. (2007). Defining academic literacies research: Issues of epistemology, ideology and strategy. Journal of Applied Linguistics, 4, 5-32.

Loi, C. K. (2010). Research article introductions in Chinese and English: A comparative genre-based study. Journal of English for Academic Purposes, 9, 267-279.

Martin, J. R. (1997). Analysing genre: Functional parameters. In F. Christie, \& J. R. Martin (Eds.), Genres and institutions: Social processes in the workplace and school (pp. 339). London: Cassell Academic.

McCarty, R., \& Swales, J. M. (2017). Technological change and generic effects in a university Herbarium: A textography revisited. Discourse Studies, 19(5), 561-580.

Moje, E. B. (2007). Developing socially just subject-matter instruction: A review of the literature on disciplinary literacy teaching. Review of Research in Education, 31, 1-44.

O'Halloran, K. (2007). Mathematical and scientific forms of knowledge: A systemic functional multimodal grammatical approach. In F. Christie, \& J. Martin (Eds.), Language, knowledge and pedagogy: Functional linguistic and sociological perspectives (pp. 205-238). London/New York: Continuum.

O'Halloran, K. (2008). Mathematical discourse: Language, symbolism and visual images. London/New York: Continuum. 
Paltridge, B., \& Starfield, S. (Eds.) (2013). The handbook of English for specific purposes. London: Wiley-Blackwell.

Sanraj, B. (2002). Introductions in research articles: Variations across disciplines. English for Specific Purposes, 21, 1-17.

Shanahan, C., Shanahan, T., \& Misischia, C. (2011). Analysis of expert readers in three disciplines: History, mathematics, and chemistry. Journal of Literacy Research, 43, 393-429.

Snow, M. A., \& Brinton, D. M. (2017). The content-based classroom: New perspectives on integrating language and content (2nd ed.). Ann Arbor, MI: University of Michigan Press.

Street, B. V. (2003). What's "new" in New Literacy Studies? Critical approaches to literacy in theory and practice. Current Issues in Comparative Education, 5(2), 77-91.

Swales, J. (1990). Genre analysis: English in academic and research settings. Cambridge: Cambridge University Press.

Tardy, C. M. (2009). Building genre knowledge. West Lafayette, Indiana: Parlor Press.

Wignell, P. (2007). Vertical and horizontal discourse and the social sciences. In F. Christie, \& J. R. Martin (Eds.), Language knowledge and pedagogy: Functional linguistic and sociological perspectives (pp. 184-204). London/New York: Continuum.

Zhang, Z. C. (2015). Disagreements in plenary addresses as multimodal action. In B. C. Camiciottoli, \& I. Fortanet-Gómez (Eds.), Multimodal analysis in academic settings: From research to teaching (pp. 17-38). London: Routledge.

Zhang, Z. C. (2016). "Somewhere in the middle is the optimal balance": A subject specialist negotiating business and language in teaching business writing. ESP Today, 4(2), 145-164. https://doi.org/10.18485/esptoday.2016.4.2.1

Zhang, Z. C. (2017). Learning business English in China: The construction of professional identity. London: Palgrave Macmillan.

ZUOCHENG ZHANG is Senior Lecturer in TESOL Education at the School of Education, University of New England, Australia. He has published extensively on Business English, discourse and identity, and multimodality, including his recent monograph, Learning business English in China: The construction of professional identity, published by Palgrave Macmillan in 2017. His current research centres around disciplinary literacies, ESP teacher development, and discourses of diversity and inclusivity in international student education.

EVELINE CHAN, Senior Lecturer in English and Literacies Education, University of New England, Australia, researches in the areas of developing academic literacies, classroom discourse analysis, multimodal representations of disciplinary knowledge, and reading in hypertext environments. Her recent publications include 'Teaching reading through multimodal texts' (with Z. Zhang) in H. P. Widodo, A. Wood, \& D. Gupta (2017) (Eds.), Asian English language classrooms: Where theory and practice meet, published by Routledge. 